\title{
A Design of Flow Electrolysis Cell for 'Home' Fabrication
}

\author{
Ana A. Folgueiras-Amador, Alex Teuten, Derek Pletcher, and Richard C. D. Brown*
}

Received 00th January 20xx, Accepted 00th January 20xx

DOI: $10.1039 / \times 0 \times x 00000 x$

\begin{abstract}
Despite a large literature on organic electrosynthesis, it has never become a routine procedure in organic synthesis laboratories. One reason is certainly a lack of attention to the design of the cell used for the electrolysis; an appropriate cell is the dominant factor in determining the rate of conversion and the final conversion. Beaker cells predominate in published laboratory electrosyntheses but their use can limit reaction performance, and ease of scale-up, particularly where high rates of conversion are required without compromising selectivity for the desired product. This paper describes a simple design of a flow cell for operation in a recycle mode that is straightforward to fabricate and its performance is illustrated with anodic and cathodic electrosyntheses. The advantages of using turbulence promoters in the flow channel and a three dimensional electrode (reticulated vitreous carbon) are demonstrated. The cell allows the preparation of up to $5 \mathrm{mmol} / \mathrm{hour}$ of isolated product, and $20 \mathrm{mmol}$ of product can be obtained over $4 \mathrm{~h}$ with high conversion of starting material. The cell design is readily scalable to enable the synthesis of larger quantities of product, and provides the capability to introduce a separator for organic electrosynthesis in a divided mode.
\end{abstract}

\section{Introduction}

Electrolysis remains attractive for organic synthesis because it achieves chemical change without expensive, toxic or hazardous reagents. It usually operates close to ambient temperature and pressure and can achieve selective transformations without the formation of secondary product streams that require treatment before discharge into the environment. Moreover, there is a very extensive literature describing many interesting and useful transformations. ${ }^{1}$ Why then is electrosynthesis not more routinely used in laboratory organic synthesis? Widely used chemical syntheses generally seek to combine good selectivity with a reasonable rate of reaction leading to a high conversion of reactant to product; experience suggests that electrosynthesis may struggle to achieve high fractional conversion in a reasonable time. One of the factors that strongly influences the performance and convenience of an electrosynthesis is the cell design.

Beaker electrolysis cells can be put together using readily available, standard laboratory items. ${ }^{2}$ However, rates of conversion can be relatively slow, requiring extended electrolysis times to reach high conversions. Moreover, the performance of a beaker cell depends on many parameters (including the dimensions of the container, the geometry, materials and dimensions of the electrodes, the distance between the working and counter electrodes, the positioning of any stirrer with respect to the electrodes and container walls, the rate of rotation of the stirrer etc.) and all this information is

a. School of Chemistry, University of Southampton, Southampton SO17 1BJ, UK + Footnotes relating to the title and/or authors should appear here.

Electronic Supplementary Information (ESI) available: [details of any supplementary information available should be included here]. See DOI: 10.1039/x0xx00000x rarely reported making it difficult to reproduce the synthesis in other laboratories. In addition, beaker cells do not facilitate scale-up of electrosynthesis; increasing the size of beaker and the electrodes according to the scale of the experiment may not be convenient, and in isolation, will not scale the synthesis satisfactorily.

Flow cells can be operated either with a reservoir and recycle of the reactant through the cell or in the single pass mode. ${ }^{3,4}$ Recently, cells with an extended cell channel length have been described and they can be successful in giving a high conversion in a single pass as well as a conversion rate of a few grams/hour. ${ }^{4}$ Such cells, however, often have features that are more challenging to fabricate and the cell design may not allow dimensions to be extended significantly where substantial scale-up is the objective. When operated in a recycle mode, flow cells can achieve much superior performance to beaker cells but still have the reputation of being expensive to purchase and complex to fabricate. ${ }^{5}$ This paper describes and characterises the design of a small flow cell with components that are easily machined and put together in a small workshop. The electrode material is conveniently exchanged and can include plates, foils or porous 3D materials such as reticulated vitreous carbon, 6 where appropriate for the chemistry targeted. The cell described is intended to allow formation of $\sim 5 \mathrm{mmol} \mathrm{h}^{-}$ 1 of product with a high conversion, but the dimensions of the cell and reservoir volume are readily increased to allow higher rates of product formation. Three electrosyntheses are used to demonstrate the capabilities of the cell.

\section{Results and discussion}

\section{Electrolysis cell description}




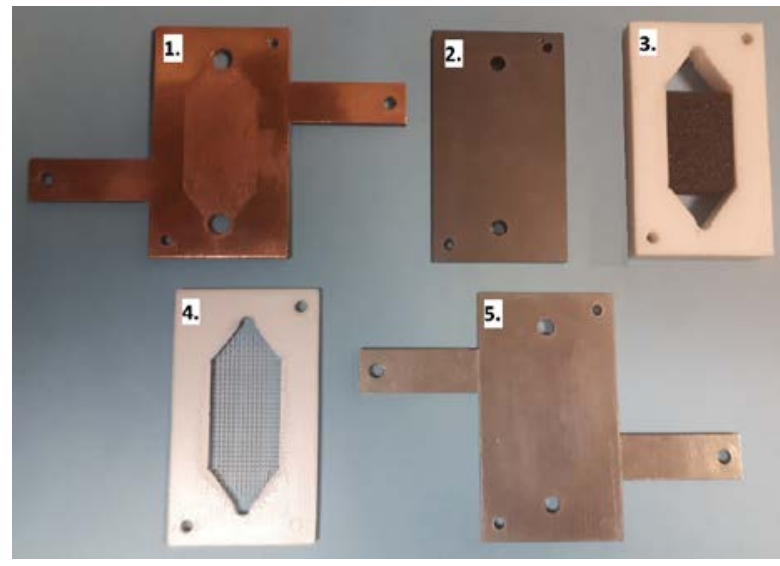

Figure 1: Components of the cell with RVC electrode: 1. Copper plate current connecto 2. Carbon/PVDF composite plate; 3. PTFE working electrode compartment with RVC anode; 4. PTFE counter electrode compartment filled with stack of fine polymer meshes; 5. Stainless steel plate cathode. For assembly, see the Supporting Information.

The components for the cell with RVC anode are shown in Figure 1. The components are: (1) a copper plate $(70 \mathrm{~mm} \times 40$ $\mathrm{mm} \times 3 \mathrm{~mm}$ thick) that ensures good and uniform electrical contact to the C/PVDF composite plate; the copper plate has ears to make electrical connection and two holes for solution entry and exit; (2) a carbon/PVDF composite plate (70 $\mathrm{mm} \times 40$ $\mathrm{mm} \times 4 \mathrm{~mm}$ thick) with holes for solution entry and exit; (3) a PTFE plate (70 mm x $40 \mathrm{~mm} \times 10 \mathrm{~mm}$ thick) with the solution compartment cut out. The central portion of the solution compartment is $30 \mathrm{~mm}$ long $20 \mathrm{~mm}$ wide and houses snugly an RVC block ( $30 \mathrm{~mm} \times 20 \mathrm{~mm} \times 10 \mathrm{~mm}$ thick). The compartment has short entry and exit lengths to smooth the flow through the cell; (4) the counter electrode compartment consisting of a PTFE plate (70 $\mathrm{mm} \times 40 \mathrm{~mm} \times 3 \mathrm{~mm}$ thick) with the centre portion cut to allow solution flow; the cut out portion is a mirror image of that in component 3 . The cut out zone is filled with a stack of 7 fine polyester meshes (1000 $\mu \mathrm{m}$ aperture) cut to the shape of the solution compartment. This stack acts as a turbulence promoter and allows the counter electrode to apply pressure across the cell to ensure good electrical connection between the RVC working electrode and the carbon/PVDF composite backing plate; (5) the other electrode is a 316 stainless steel plate ( $70 \mathrm{~mm} \times 40 \mathrm{~mm} \times 3 \mathrm{~mm}$ thick) with ears to make electrical connection and two holes (diameter $4.77 \mathrm{~mm}$ ) for solution entry and exit with connectors to $3 / 16$ inch tubing. All components have small holes in two corners to allow their facile alignment with two thin rods during assembly. Leak free operation was ensured by clamping the cell within two aluminium endplates with 6 bolts (torque: 3-4 Nm). A thin insulating polymer sheet was placed between the steel and copper electrodes/current contacts and the aluminium endplates. CAD drawings of the components are included in the Supporting Information.

For experiments without an RVC electrode, the cell set-up was similar except the $10 \mathrm{~mm}$ thick solution compartment was removed and the interelectrode gap was formed with only the $3 \mathrm{~mm}$ thick compartment. There was the option of filling the central space with a stack of fine polymer meshes. The cell could also be operated in a separated mode by including a Nafion ${ }^{\circledR}$
438 membrane between the two polymer solution compartments.

PTFE tubing $\left(1 / 8^{\prime \prime} \times 3 / 16^{\prime \prime}\right)$ was used to connect the solution reservoir to the cell. Flangeless PEEK fittings 5/16-24" flatbottom (for 3/16" OD tubing) and Flangeless PEEK fittings 1/4-28" flat-bottom (for 1/8" OD tubing) were purchased from Kinesis (Part No. XP-132 and XP-330 respectively). The reaction solution was prepared in a conical flask and stirred during the electrolysis to ensure homogeneity.

\section{Electrosyntheses}

Initially, the performance of the cell was examined using anodic methoxylation of $\mathrm{N}$-formylpyrrolidine (1) as a model reaction (Figure 2).7, 4d,e Electrolyses were carried out with $50 \mathrm{~mL}$ of a 0.1 $\mathrm{M}$ solution of $\mathrm{N}$-formylpyrrolidine (1) + $0.05 \mathrm{M} \mathrm{Et}_{4} \mathrm{NBF}_{4}$ in $\mathrm{MeOH}$ cycling through the flow cell. The fractional conversion of $\mathbf{1}$ to 2-methoxy- $N$-formylpyrrolidine (2) is reported as a function of time for three electrolyses with different cell configurations (Figure 2); the flow rate of the reactant solution was $36 \mathrm{~mL} \mathrm{~min}^{-}$ 1 and the cell current was $160 \mathrm{~mA}$. This cell current was selected after determining the cell currents for a mass transfer controlled reaction in three different cell configurations (see Supporting Information). ${ }^{4 d}$ Enhanced mass transfer in the reactor is achieved by increasing the flow rate of the reactant solution, and $36 \mathrm{~mL} \mathrm{~min}^{-1}$ provides a good level of mixing within the capability of typical laboratory pumps. With the flat plate anode, the conversion of $\mathbf{1}$ to $\mathbf{2}$ increases steadily with time but the fractional conversion reaches only 0.4 after $1 \mathrm{~h}$ and thereafter increases only very slowly.

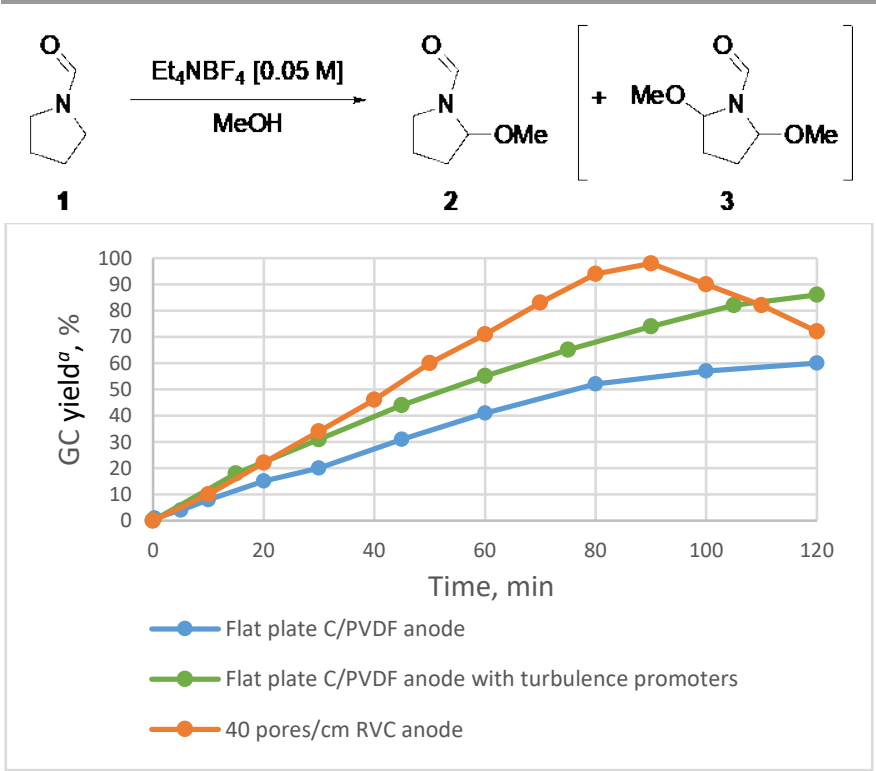

Figure 2. Anodic methoxylation of $\mathrm{N}$-formylpyrrolidine (1). Fractional conversion of $\mathbf{1}$ to 2-methoxy- $\mathrm{N}$-formylpyrrolidine (2) as a function of time. Solution was $50 \mathrm{~mL}$ of $0.1 \mathrm{M} \mathrm{N}$ formylpyrrolidine $+0.05 \mathrm{M} \mathrm{Et}_{4} \mathrm{NBF}_{4}$ in $\mathrm{MeOH}$. Solution flow rate: $36 \mathrm{~mL} \mathrm{~min}{ }^{-1}$. Cell current: $160 \mathrm{~mA} .{ }^{a} \mathrm{GC}$ calibrated using solutions of $\mathbf{1}$ of known concentrations.

Improving the mass transfer in the cell by filling the solution compartment with a stack of polymer meshes to act as turbulence promoters, led to a modest improvement in the rate 
of conversion (fractional conversion of 0.55 after $1 \mathrm{~h}$ ). A more substantial increase in the rate of conversion was achieved by filling the solution compartment with a three dimensional anode separated from the counter electrode by a stack of fine polymer meshes. With the reticulated vitreous carbon anode having a high electrode area and giving effective turbulence promotion, the conversion after $1 \mathrm{~h}$ rises to 0.70 and conversion continues at a good rate reaching $97 \%$ after $90 \mathrm{~min}$, and with a high current efficiency (89\%). Extending the electrolysis beyond this conversion leads to some over oxidation to the dimethoxyderivative 3.

Clearly, the RVC anode is a valuable asset in designing convenient synthesis and a reaction giving a fractional conversion $>0.9$ of $5 \mathrm{mmol}$ of compound in $80 \mathrm{~min}$ is usually acceptable for many practical research laboratory applications. The optimal performance of three dimensional electrodes, however, requires all the electrode surface being active and this depends on a favourable potential distribution throughout the 3-D structure; IR drop through the solution tends to reduce this activity with distance through the electrode away from the counter electrode. ${ }^{5 a, b}$ In order to explore this limitation, a series of electrolyses were carried out with a much lower reactant concentration, $0.01 \mathrm{M}$, thereby reducing the local current densities and hence these IR drops. Figure 3 reports fractional conversion $v s$ time for three cell currents with the RVC anode cell with a feed solution containing $0.01 \mathrm{M} \mathrm{N}$-formylpyrrolidine (1) and $0.05 \mathrm{M} \mathrm{Et}_{4} \mathrm{NBF}_{4}$ in $\mathrm{MeOH}$. With this reactant concentration, full conversion can be achieved and the time to full conversion is decreased significantly. It is also seen that continuing the electrolysis beyond full conversion leads to over oxidation with the mono-methoxylated product to the dimethoxylated product 3. Di-methoxylated product $\mathbf{3}$ is not formed, however, at lower conversions and this is an indication that mono-methoxylated product $\mathbf{2}$ is significantly more difficult to oxidise than $N$-formylpyrrolidine (1); its oxidation potential is much more positive.

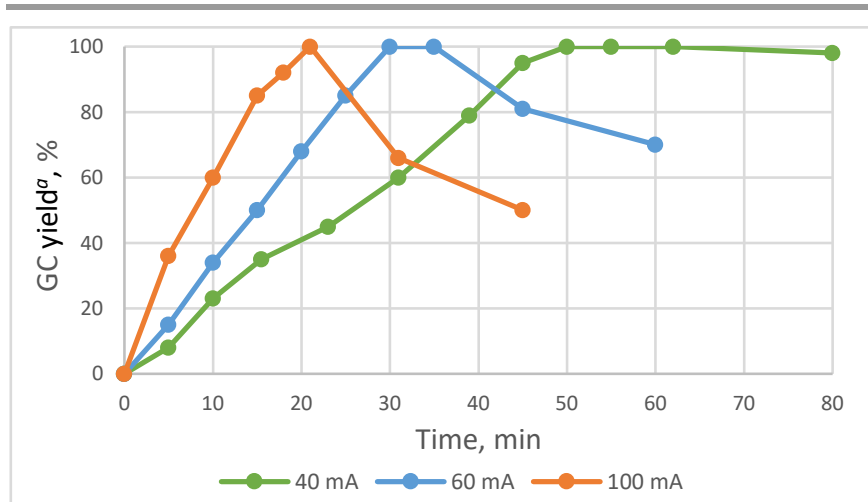

Figure 3. Fractional conversion of $N$-formylpyrrolidine (1) to 2-methoxy- $N$ formylpyrrolidine (2) as a function of time with the RVC anode. Solution was $50 \mathrm{~mL}$ of $0.01 \mathrm{M} \mathrm{N}$-formylpyrrolidine $+0.05 \mathrm{M} \mathrm{Et}_{4} \mathrm{NBF}_{4}$ in methanol. Solution flow rate: $36 \mathrm{~mL} \mathrm{~min}^{-}$ 1. Cell current: $40 \mathrm{~mA}$ (green), $60 \mathrm{~mA}$ (blue), $100 \mathrm{~mA}$ (orange). ${ }^{a} \mathrm{GC}$ calibrated using solutions of $\mathbf{1}$ of known concentrations.

The fastest conversion is observed with the highest cell current when a fractional conversion of 0.9 is achieved in $17 \mathrm{~min}$ and at this time, the fractional current efficiency is $>0.9$. With a current of $100 \mathrm{~mA}$, the cell is operating close to mass transfer control throughout the structure as may be shown by fitting the conversion vs time data to equation SI3 (see Supporting Information) with a value $k_{m} A_{e}=0.02 \mathrm{~s}^{-1} .5 \mathrm{~b}, 8$ This is very similar to the value obtained from voltammetry for the reduction of ferricyanide (see Supporting Information) and the deposition of copper from an acid sulfate solution. ${ }^{8,9}$ With the lower cell currents ( 40 and $60 \mathrm{~mA}$ ), the oxidation takes longer because the electrode reaction is not fully mass transfer controlled (Figure 3 , green and blue lines, respectively), and the reaction rate depends on the current applied.

In order to increase the productivity of the cell with the RVC anode, the influence of cell current on electrolyses with $0.1 \mathrm{M}$ $\mathrm{N}$-formylpyrrolidine was investigated (Figure 4). With a cell current of $160 \mathrm{~mA}$, a fractional conversion of 0.9 was reached after $80 \mathrm{~min}$. This corresponds to a productivity of $3.4 \mathrm{mmol} \mathrm{h}^{-}$ ${ }^{1}\left(0.4 \mathrm{~g} \mathrm{~h}^{-1}\right)$. In terms of both conversion and productivity this small cell is achieving a satisfactory performance for many laboratory syntheses. Doubling the cell current can be seen to allow much faster electrolysis reaching a similar conversion in only 50 minutes, but it was not possible to increase the amount of the product 2 further using this cell current; continuing electrolysis led to loss of 2-methoxy- $N$-formylpyrrolidine (2) and formation of the di-methoxylated product 3. It was, however possible to achieve a higher conversion to $\mathbf{2}$ by reducing the cell current to $160 \mathrm{~mA}$ after 40 minutes. Under these conditions, the current efficiency is $95 \%$ and the electrolysis time is reduced by about $30 \%$. This illustrates the advantage of reducing the cell current periodically during the electrolysis.

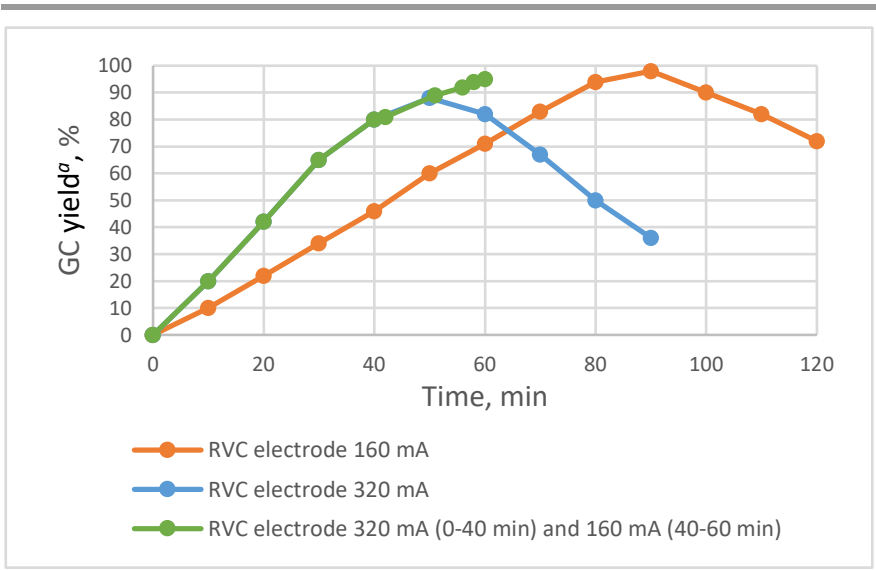

Figure 4. Fractional conversion of $\mathrm{N}$-formylpyrrolidine to 2-methoxy- $\mathrm{N}$-formylpyrrolidine as a function of time with the RVC anode. Solution was $50 \mathrm{~mL}$ of $0.1 \mathrm{M}$ $\mathrm{N}$-formylpyrrolidine $+0.05 \mathrm{M} \mathrm{Et}_{4} \mathrm{NBF}_{4}$ in methanol. Solution flow rate: $36 \mathrm{~mL} \mathrm{~min}{ }^{-1}$. Cell current: $160 \mathrm{~mA}$ (orange line), $320 \mathrm{~mA}$ (blue line), $320 \mathrm{~mA}$ for 40 minutes, $160 \mathrm{~mA}$ thereafter (green line). ${ }^{a} \mathrm{GC}$ calibrated using solutions of $\mathbf{1}$ of known concentrations.

The capabilities of the cell are further illustrated by two electrosynthetic transformations. The first reaction was anodic decarboxylative etherification of 1-adamantanecarboxylic acid (4) to form the methoxylated product 5 using $5 \mathrm{~mol} \%$ of $\mathrm{K}_{2} \mathrm{CO}_{3}$ as a base to form the oxidisable carboxylate species, which also serves as supporting electrolyte to improve the conductivity of the medium (Scheme 1). ${ }^{10}$ When carried out with the RVC anode, only a single product was formed and the conversion 
was $80 \%$ after 2 hours, while with the flat C/PVDF electrode the reaction only reached $25 \%$ conversion (see Supporting Information).
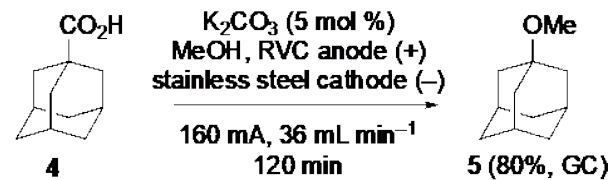

Scheme 1. Electrochemical methoxylation of adamantane using anodic decarboxylation

The second reaction explored concerned electrochemical transformation of $\mathrm{N}$-PMB 4-iodobenzamide (6, Scheme 2), a substrate that is electroactive at both anode and cathode. When electrolysis of $\mathbf{6}$ was conducted in the undivided recycle cell, the major product was compound 7 . Both reductive $\mathrm{C}-1$ bond cleavage at the cathode and anodic methoxylation $\alpha$ to the nitrogen atom occurred; subsequent cleavage of aminal 7 to give benzamide required an acid treatment following the electrolysis (without a separator cathodic processes maintain neutrality of the electrolyte). Selective oxidative cleavage of the PMB group from 6 was realised by introducing a Nafion ${ }^{\circledR} 438$ membrane between anolyte and catholyte chambers. The deprotected product, 2-iodobenzamide (9), was obtained with a fractional conversion of 0.66 after $90 \mathrm{~min}(2.5 \mathrm{mmol}$ scale) using a flat C/PVDF electrode at $160 \mathrm{~mA}$, with full consumption of 6 after $165 \mathrm{~min}$ ( $90 \%$ isolated yield, 27\% current efficiency). In this divided mode the anolyte becomes acid so that the aminal cleavage occurs in situ within the cell giving 9 directly. A substantial improvement in the efficiency of the anodic process was obtained using a three dimensional RVC electrode, delivering full conversion of 6 to 9 in 55 min (89\% isolated yield, $81 \%$ current efficiency).
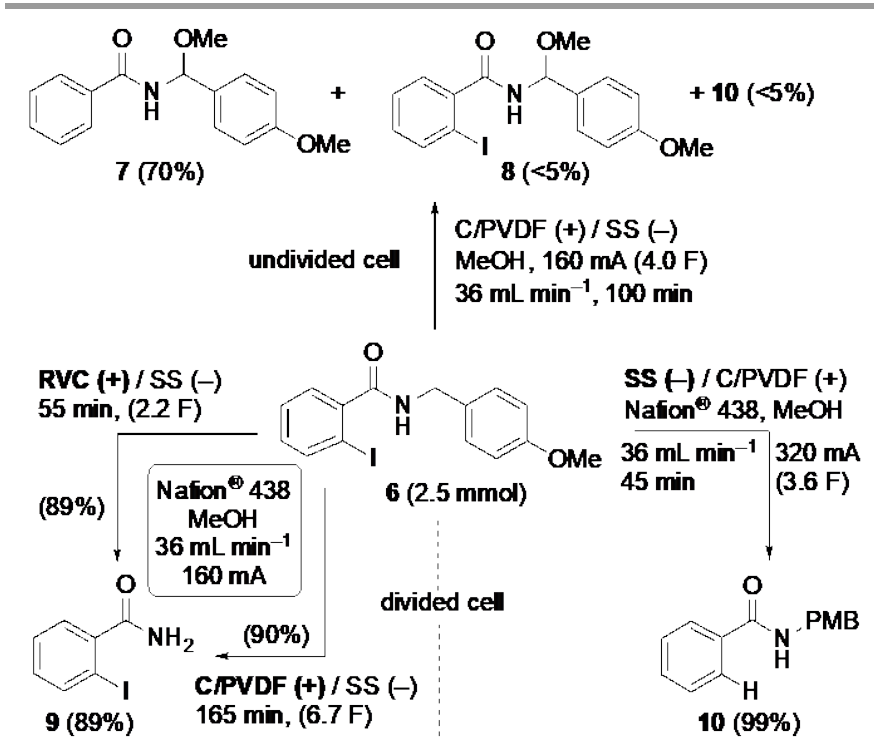

Scheme 2. Selective anodic and cathodic transformations of compound $\mathbf{6}$ in divided cell.

It is also possible to reduce compound $\mathbf{6}$ selectively using a divided cell. The dehalogenated benzamide $\mathbf{1 0}$ ( $2.5 \mathrm{mmol})$ was obtained in $99 \%$ yield in 45 min by carrying out the electrolysis on a stainless steel cathode at $320 \mathrm{~mA}$. In the cathodic reaction, full conversion was achieved at a faster rate, but using an excess of current ( $55 \%$ current efficiency).

\section{Discussion}

The purpose of this paper is not to claim superior performance of the described cell compared to commercial flow electrolysis cells (e.g. Ammonite, ${ }^{11}$ C-Flow cells, ${ }^{12}$ ElectroCell, ${ }^{13}$ Electrasyn flow, ${ }^{14}$ Vapourtec $\left.{ }^{15}\right)$. Rather the objective is to show that a flow cell suitable for electrosynthesis can readily be put together in one's own laboratory. The cell described operates leak free and can deliver a high conversion and a gram of product within two hours when an RVC anode is included. Increasing cell productivity and/or the rate of electrolysis can be achieved by (a) having a larger electrode area by increasing the width and length of the two electrodes (in each case with an appropriate increase in other component dimensions and the cell current); (b) increasing the flow rate of the reactant solution through the cell to improve the mass transfer regime; (c) introducing features (e.g. mesh stacks) into the cell to improve the mass transfer regime; (d) increasing the concentration of reactant. A larger amount of product can also be obtained by simply increasing the volume of reactant solution in the reservoir, with a commensurate extension of electrolysis time.

Clearly, including the reticulated vitreous carbon as the working electrode enhances significantly the performance of the cell. The performance of such a three dimensional electrode is limited by IR drop through the structure and this restricts the thickness of the RVC that can be used and operation to media with a sufficient conductivity. For laboratory organic electrosynthesis, it is sufficient to note that an adequate performance can be reached with an electrode thickness of 10 $\mathrm{mm}$ and a medium such as $\mathrm{MeOH} / 0.05 \mathrm{M} \mathrm{Et}_{4} \mathrm{NBF}_{4}$.

It should be noted that in the anodic electrosyntheses herein, the counter electrode reaction is hydrogen evolution with the formation of base $\left(\mathrm{MeO}^{-}\right)$. In undivided mode, methoxide formed reacts with protons formed during the anodic reaction balancing the $\mathrm{pH}$ of the electrolyte solution. Cathodic hydrogen evolution does not appear to degrade the performance of this cell under the high flow rates employed, and may even improve the mass transfer regime to the anode. ${ }^{16}$

Many different electrode materials can be used if available as flat plates, thin foils or coatings on thin foil; the foil can simply be laid on the steel and copper electrodes so that they then operate as current contacts.

It should be noted that the electrolyses were carried out using a constant current power supply to control the cell. Suitable power supplies are available in many laboratories. A controlled potential mode of operation is also possible but requires a potentiostat, which is not as commonly available. They are also more expensive than a power supply and frequently limit the cell current that can be used (increasing the electrolysis time). We believe that constant current operation is better suited to electrolyses in synthetic organic chemistry laboratory. Good performance is, however dependent on the choice of an appropriate cell current. Too low a value will lead to a longer electrolysis time while too high a value will lead to competing electrode reactions, causing a lower current efficiency and 
risking overoxidation and/or other byproducts. To give the fastest electrolysis, the initial cell current should be selected so that the electrode reaction is close to mass transfer control and estimates for the parameters determining mass transfer in a flow cell as a function of flow rate are available in the literature. ${ }^{5,6 a, 8 a}$ Even so, the influence of cell current on performance should be explored experimentally if an optimum performance is desirable. Periodically reducing the cell current as the reactant is consumed is always an option.

\section{Experimental}

\section{2-Methoxy-N-formylpyrrolidine (2)}

The reactor was assembled in undivided mode with the RVC anode and a stainless steel cathode. The reactor chamber was filled with turbulence promoter mesh stacks.

Electrolysis in undivided mode was carried out using a solution of $\mathrm{N}$-formylpyrrolidine $(\mathbf{1}, 496 \mathrm{mg}, 5.00 \mathrm{mmol})$ and $\mathrm{Et}_{4} \mathrm{NBF}_{4}$ (543 mg, $2.50 \mathrm{mmol})$ in $\mathrm{MeOH}(50 \mathrm{~mL})$. The reactor inlet and outlet tubes were inserted into the reservoir solution to allow continuous recycling. The current was adjusted to $320 \mathrm{~mA}(40$ $\mathrm{min}$ ) then $160(20 \mathrm{~min})$ and the flow rate to $36 \mathrm{~mL} \mathrm{~min}^{-1}$. When electrolysis was complete $(2.0 \mathrm{~F}$, full conversion of 1$)$, the solvent was removed under reduced pressure. The product was extracted into EtOAc, with recovery of supporting electrolyte by filtration. Removal of solvent under reduced pressure afforded the methoxylated product as a colourless oil $(627 \mathrm{mg}, 4.85$ mmol, 97\%). No further purification was required. ${ }^{18}$ Spectroscopic and physical data for $\mathbf{2}$ are consistent with reported values. ${ }^{7 e}$

\section{1-Methoxyadamantane (5)}

The reactor was assembled in undivided mode with the RVC anode and a stainless steel cathode. The reactor chamber was filled with turbulence promoter mesh stacks.

Electrolysis in undivided mode was carried out using a solution of 1-adamantanecarboxylic acid $(4,901 \mathrm{mg}, 5.00 \mathrm{mmol})$ and $\mathrm{K}_{2} \mathrm{CO}_{3}$ (34.5 mg, $0.250 \mathrm{mmol}$ ) in $\mathrm{MeOH}(50 \mathrm{~mL}$ ). The reactor inlet and outlet tubes were inserted into the reservoir solution to allow continuous recycling. The current was adjusted to $160 \mathrm{~mA}$ (120 $\mathrm{min}$ ) and the flow rate to $36 \mathrm{~mL} \mathrm{~min}{ }^{-1}$. When electrolysis was complete $(2.4 \mathrm{~F}$, full conversion of 4 ), the solvent was carefully removed under reduced pressure. Due to the volatile nature of $\mathbf{5}$, yields were determined using calibrated GC analysis (80\%). A purified sample of 1-methoxyadamantane (5) was obtained as a colourless oil (449 $\mathrm{mg}, 2.7 \mathrm{mmol}, 54 \%$ ) by Kugelrohr distillation $\left(40{ }^{\circ} \mathrm{C}\right.$ at 15 mbar) of the crude reaction mixture. Spectroscopic and physical data for $\mathbf{9}$ are consistent with reported values. ${ }^{19}$

Electrolysis of 2-iodo- $N$-(4-methoxybenzyl)benzamide (6)

\section{$N$-(Methoxy(4-methoxyphenyl)methyl)benzamide (7)}

The reactor was assembled in undivided mode with the RVC anode and a stainless steel cathode. The reactor chamber was filled with turbulence promoter mesh stacks.

Electrolysis in undivided mode was carried out using a solution of 2-iodo- $N$-(4-methoxybenzyl)benzamide (6, $918 \mathrm{mg} 2.50$ $\mathrm{mmol}$ ) and $\mathrm{Et}_{4} \mathrm{NBF}_{4}(272 \mathrm{mg}, 1.25 \mathrm{mmol})$ in $\mathrm{MeOH}(25 \mathrm{~mL})$. The reactor inlet and outlet tubes were inserted into the reservoir solution to allow continuous recycling of the reaction solution. The current was adjusted to $160 \mathrm{~mA}$ and the flow rate to $36 \mathrm{~mL}$ $\mathrm{min}^{-1}$. After $100 \mathrm{~min}$ of electrolysis $(4.0 \mathrm{~F}$, full conversion of 6$)$, the solvent was removed under reduced pressure. The supporting electrolyte (254 mg, 93\%) was recovered by precipitation from EtOAc $(15 \mathrm{~mL})$. Removal of solvent under reduced pressure afforded a yellow solid. Purification by flash chromatography (EtOAc/hexane, 1:4) afforded the title compound 7 as a colourless solid (474 mg, $1.75 \mathrm{mmol}, 70 \%$ ). Spectroscopic and physical data for $\mathbf{7}$ are consistent with reported values. ${ }^{20}$

\section{2-lodobenzamide (9)}

The reactor was assembled in divided mode with the RVC anode and a stainless steel cathode. A Nafion ${ }^{\circledR} 438$ membrane was placed between the PTFE gaskets of the anode and cathode compartments, the latter was filled with turbulence promoter mesh stacks. The current was adjusted to $160 \mathrm{~mA}$ and the flow rate to $36 \mathrm{~mL} \mathrm{~min}^{-1}$.

Anolyte: Electrolysis was carried out using a solution of 2-iodo$\mathrm{N}$-(4-methoxybenzyl)benzamide $(6,0.918 \mathrm{~g}, 2.50 \mathrm{mmol})$ and $\mathrm{Et}_{4} \mathrm{NBF}_{4}(0.272 \mathrm{~g}, 1.25 \mathrm{mmol})$ in $\mathrm{MeOH}(25 \mathrm{~mL})$. The anolyte reservoir was connected to the pump for the anodic compartment, and the outlet of the reactor was inserted into the same reservoir to allow continuous recycling of the reaction solution. After $55 \mathrm{~min}$ of electrolysis (2.2 F, full conversion of 6), the anolyte solution was added to sat. aq. $\mathrm{NaHCO}_{3}(10 \mathrm{~mL})$. The volume of the resulting solution was reduced to approximately $50 \%$, under reduced pressure, then extracted with EtOAc ( $3 \times 10$ $\mathrm{mL}$ ). The combined organic phase was washed with sat. aq. $\mathrm{NaHSO}_{3}(10 \mathrm{~mL})$ to remove the $\mathrm{PMB}$ aldehyde co-product. The organic solution was dried over $\mathrm{MgSO}_{4}$, filtered and solvent was removed under reduced pressure to afford a brown paste. Recrystallisation from EtOAc afforded the title benzamide 9 as a colourless solid (550 mg, $2.23 \mathrm{mmol}, 89 \%$ ). Spectroscopic and physical data for $\mathbf{9}$ are consistent with reported values. ${ }^{21}$

Catholyte: The electrolysis was carried out using a solution of $\mathrm{Et}_{4} \mathrm{NBF}_{4}(0.272 \mathrm{~g}, 1.25 \mathrm{mmol})$ in $\mathrm{MeOH}(25 \mathrm{~mL})$. The catholyte reservoir was connected to the pump for the cathodic compartment, and the outlet of the reactor was inserted into the same reservoir to allow continuous recycling of the solution. N-(4-Methoxybenzyl)benzamide (10)

The reactor was assembled with a C/PVDF anode and a stainless steel cathode. A Nafion ${ }^{\circledR} 438$ membrane was placed between the PTFE gaskets of the anode and cathode compartment. Turbulence promoters were used in both anodic and cathodic compartments. The current was adjusted to $320 \mathrm{~mA}\left(16 \mathrm{~mA} \mathrm{~cm}^{-}\right.$

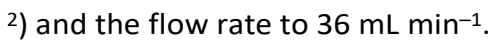

Anolyte: Electrolysis was carried out using a solution of $\mathrm{Et}_{4} \mathrm{NBF}_{4}$ (0.272 g, $1.25 \mathrm{mmol}$ ) in $\mathrm{MeOH}(25 \mathrm{~mL})$. The anolyte reservoir was connected to the pump for the anodic compartment, and the outlet of the reactor was inserted into the same reservoir to allow continuous recycling.

Catholyte: Electrolysis was carried out using a solution of 2iodo- $N$-(4-methoxybenzyl)benzamide $(6,0.918 \mathrm{~g}, 2.50 \mathrm{mmol})$ 
and $\mathrm{Et}_{4} \mathrm{NBF}_{4}(0.272 \mathrm{~g}, 1.25 \mathrm{mmol})$ in $\mathrm{MeOH}(25 \mathrm{~mL})$. The catholyte reservoir was connected to the pump for the cathodic compartment, and the outlet of the reactor was inserted into the same reservoir to allow continuous recycling. After $45 \mathrm{~min}$ of electrolysis (3.6 F, full conversion of 6 ), the solvent was removed under reduced pressure. The supporting electrolyte $(0.258 \mathrm{~g}, 95 \%)$ was recovered by precipitation from EtOAc (15 $\mathrm{mL}$ ). Removal of solvent under reduced pressure afforded compound 10 as a pale yellow solid (597 mg, $2.47 \mathrm{mmol}, 99 \%$ ). No further purification was required. Spectroscopic and physical data for $\mathbf{1 0}$ are consistent with reported values. ${ }^{22}$

\section{Conclusions}

A simple flow electrolysis cell is described, which is straightforward to fabricate, and designed for operation in a recycle mode in order to achieve high conversion. The design provides the capability to introduce a separator for organic electrosynthesis in a divided mode. Selectivity and rate of conversion are important considerations in organic electrosynthesis, and these are optimised when the electrode reaction is close to mass transfer control. The mass transfer characteristics of the flow cell are improved by increasing flow rate and by introducing mesh stacks as turbulence promoters into the flow channel. Furthermore, the value of a three dimensional electrode (here, reticulated vitreous carbon) is demonstrated by the delivery of improved fractional conversion in shorter times. The performance cell is illustrated by anodic and cathodic organic electrosyntheses, in undivided and divided configurations, allowing the preparation of 3-5 mmol/hour of isolated product. Furthermore, the cell design itself is readily scalable to enable the synthesis of larger quantities when required. We believe that the cell design described herein, along with practical considerations to improve performance, will prove valuable to others wishing to perform electrosyntheses in flow.

\section{Conflicts of interest}

There are no conflicts to declare.

\section{Acknowledgements}

The authors are grateful to Carlos Ponce de León and Luis Fernando Arenas (The University of Southampton) for useful discussion relating to the cell design and construction. The authors acknowledge financial support from EPSRC (PhotoElectro Programme Grant EP/P013341/1 and EP/K039466/1).

\section{Notes and references}

1 For selected reviews: (a) Organic Electrochemistry, 5th ed.; Hammerich, O., Speiser, B., Eds.; CRC Press: Boca Raton, 2015. (b) J. Yoshida, K. Kataoka, R. Horcajada, Chem. Rev. 2008, 108, 2265; (c) B. A. Frontana-Uribe, R. D. Little, J. G. Ibanez, Green Chem. 2010, 12, 2099; (d) R. Francke, R. D. Little, Chem. Soc. Rev. 2014, 43, 2492; (e) E. Horn, J. B. R. Rosen, P. S. Baran, ACS
Cent. Sci. 2016, 2, 301; (f) M. Yan, Y. Kawamata, P. S. Baran, Chem. Rev. 2017, 117, 13230; (g) S. Mohle, M. Zirbes, E. Rodrigo, T. Gieshoff, A. Wiebe, S. R. Waldvogel, Angew. Chem. Int. Ed. 2018, 57, 6018; (h) A. Shatskiy, H. Lundberg, M. D. Kärkäs, ChemElectroChem 2019, 6, 4067; (i) N. Shei, A. Listratova, A. A. Titov, L. G. Voskressensky, Synthesis, 2019, 51, 2455.

2 (a) M. Yan, Y. Kawamata, P. S. Baran, Angew. Chem. Int. Ed. 2018, 57, 4149; (b) R. D. Little, K. D. Moeller, Chem. Rev. 2018, $118,4483$.

3 Selected examples of flow electrochemical flow reactors for organic synthesis: (a) C. Gütz, A. Stenglein, S. R. Waldvogel, Org. Process Res. Dev. 2017, 21, 771; (b) A. A. FolgueirasAmador, T. Wirth, Chapter 5: Electrochemistry under flow Conditions in Flow Chemistry: Integrated Approaches for Practical Applications, (Ed: S. V. Luis and E. García-Verdugo) RSC, Croydon, 2020, pp. 153-198; (c) M. Atobe, H. Tateno, Y. Matsumura, Chem. Rev. 2018, 118, 4541; (d) Y. Mo, K. F. Jensen, Chem. Eur. J. 2018, 24, 10260; (e) T. Noël, Y. Cao, G. Laudadio, Acc. Chem. Res. 2019, 52, 2858; (f) F. C. Walsh, L. F. Arenas, C. Ponce-de-León, Curr. Opin. Electrochem. 2019, 16, 10. (g) B. Gleede, M. Selt, C. Gütz, A. Stenglein and S. R. Waldvogel, Org. Process Res. Dev. 2020, DOI: 10.1021/acs.oprd.9b00451.

4 Extended channel electrochemical flow reactors: (a) R. A. Green, R. C. D. Brown, D. Pletcher, B. Harji, Electrochem. Commun. 2016, 73, 63; (b) R. A. Green, R. C. D. Brown, D. Pletcher, J. Flow Chem. 2016, 6, 191; (c) D. Pletcher, R. A. Green, R. C. D. Brown, Chem. Rev. 2018, 118, 4573; (d) J. Kuleshova, J. T. Hill-Cousins, P. R. Birkin, D. Pletcher, T. J. Underwood, R. C. D. Brown, Electrochim. Acta, 2012, 69, 197; (e) N.Amri, R. A. Skilton, D. Guthrie, T. Wirth, Synlett 2019, 30, 1183.

5 (a) D. Pletcher, F. C. Walsh, Industrial Electrochemistry, 2nd ed.; Chapman and Hall: London, 1990; (b) F. C. Walsh, A First Course in Electrochemical Engineering; The Electrochemical Consultancy: Romsey, 1993; (c) F. C. Walsh, C. Ponce-de-León, Electrochim. Acta 2018, 280, 121.

6 (a) M. Friedrich, C. Ponce-de-León, G. W. Reade, F. C. Walsh, J. Electroanal. Chem. 2004, 561, 203; (b) F. C. Walsh, L. F. Arenas, C. Ponce-de-León, G. W. Reade, I. Whyte, B. G. Mellor, Electrochim. Acta 2016, 215, 566.

7 (a) K. Nyberg, R. Servin, Acta Chim. Scand. B 1976, 30, 640642; (b) L. Eberson, J. Hlavaty, L. Jonsson, K. Nyberg, R. Servin, H. Sternerup, L. G. Wistrand, Acta Chim. Scand. B 1979, 33, 113; (c) P. D. Palasz, J. H. P. Utley, J. D. Hardstone, J. Chem. Soc. Perkin Trans. II 1984, 807; (d) R. A. Green, R. C. D. Brown, D. Pletcher, J. Flow Chem. 2015, 5, 31. (e) R. A. Green, R. C. D. Brown, D. Pletcher, Org. Process Res. Dev. 2015, 19, 1424.

8 (a) D. Pletcher, I. Whyte, F. C. Walsh, J. P. Millington, J. Appl. Electrochem. 1991, 21, 659; (b) D. Pletcher, I. Whyte, F. C. Walsh, J. P. Millington, J. Appl. Electrochem. 1993, 23, 82.

9 (a) J. A. van Zorge, J. Strating, H. Wynberg, Recl. des Trav. Chim. des Pays-Bas 1970, 89, 781. (b) D. Pletcher, I. Whyte, F. C. Walsh, J. P. Millington, J. Appl. Electrochem. 1971, 21, 667.

10 For selected reviews of anodic decarboxylation (a) $\mathrm{H}$. J. Schäfer, in Top. Curr. Chem. Electrochem. IV (Ed.: E. Streckhan), Springer, Berlin, Vol. 152, 1990, pp. 91-151; (b) H. J. Schäfer, in Compr. Org. Synth. (Eds.: B.M. Trost, I. Fleming), Pergamon Press, Vol. 3, 1991, pp. 633-658. For recent examples of anodic decarboxylative etherification: (c) J. Xiang, M. Shang, Y. Kawamata, H. Lundberg, S. H. Reisberg, M. Chen, P. Mykhailiuk, G. Beutner, M. R. Collins, A. Davies, et al., Nature 2019, 573, 398; (d) D. E. Collin, A. A. FolgueirasAmador, D. Pletcher, M. E. Light, B. Linclau, R. C. D. Brown, Chem. Eur. J. 2020, 26, 374.

11 Ammonite 8: www.cambridgereactordesign.com

12 C-Flow: www.c-flow.co.uk 
13 ElectroCell: www.electrocell.com

14 Electrasyn flow: www.ikaprocess.com/en/Products/

15 Vapourtech: www.vapourtec.com/products/flow-reactors/

16 A. A. Folgueiras-Amador, K. E. Jolley, P. R. Birkin, R. C. D. Brown, D. Pletcher, S. Pickering, M. Sharabi, O. de Frutos, C. Mateos, J. A. Rincón, Electrochem. Commun. 2019, 100, 6.

17 M. Jithunsa, M. Ueda, O. Miyata, Org. Lett. 2011, 13, 518.

18 Where conversion is incomplete the crude mixture was distilled by Kugelrohr $\left(65^{\circ} \mathrm{C}\right.$ at $1 \mathrm{mbar}$ to remove starting material, then $100{ }^{\circ} \mathrm{C}$ at $1 \mathrm{mbar}$ ) to afford 2 as a colourless oil.

19 S. Inomata, Y. Harada, S. Matsuoka, and T. Ishizone, Tetrahedron, 2013, 69, 3238.

20 A. R. Katritzky, W. Q. Fan, M. Black and J. Pernak, J. Org. Chem., 1992, 57, 547.

21 S. Shimokawa, Y. Kawagoe, K. Moriyama and H. Togo, Org. Lett., 2016, 18, 784.

22 C. Liu, S. Liao, Q. Li, S. Feng, Q. Sun, X. Yu and Q. Xu, J. Org. Chem. 2011, 76, 5759-5773. 